\title{
Sensitivity of Lichens to Diesel Exhaust under Laboratory Conditions
}

\author{
Ulrike Langmann1, Pierre Madl'², Roman Türk¹, Werner Hofmann², Georg Brunauer¹ \\ ${ }^{1}$ Department of Organismic Biology, University of Salzburg, Salzburg, Austria \\ ${ }^{2}$ Department of Materials Research \& Physics, University of Salzburg, Salzburg, Austria \\ Email: ulrike.langmann@gmail.com
}

Received 13 August 2014; revised 8 September 2014; accepted 1 October 2014

Copyright (C) 2014 by authors and Scientific Research Publishing Inc.

This work is licensed under the Creative Commons Attribution International License (CC BY). http://creativecommons.org/licenses/by/4.0/

(c) (i) Open Access

\begin{abstract}
Lichen vegetation reacts very sensitively to a variety of air pollutants including increased nitrogen concentrations as well as to traffic exhaust in general, which makes lichens reliable monitoring organisms for atmospheric pollution. Recent environmental studies have shown that decreasing abundance of acidophytic lichen species and the increase of nitrophytic lichens can be explained by elevated levels of atmospheric nitric-compounds adsorbed onto nanoparticles. One major source of these atmospheric compounds amongst a wider pollution inventory is diesel exhaust-a mixture of gases and particle matter. This study aimed to shed light on the impact of diesel exhaust on the viability of six differently sensitive lichen species. Diesel exhaust particle concentrations in the laboratory experiments resembled those at a local highway during rush hour. By incubation in a closed stainless steel chamber we could exclude influences from other pollutants than diesel exhaust providing explicit data about the effects of diesel exhaust on lichens. The investigations revealed effects on the photosynthesis of the lichen photobionts and hence the lichen vitality. The conclusions of this study are that 1) the photobiont is affected stronger as the mycobiont and 2) older parts of the lichen are damaged first. Another remarkable result of this study is that 3 ) these lichens are regenerating to some extent during incubation-free periods-unless the organism is not damaged too much to restore photosynthetic activity. To our knowledge this is the first study evaluating the impact of diesel exhaust on lichens under laboratory conditions separate from other interfering pollutants.
\end{abstract}

\section{Keywords}

Lichens, Biomonitors, Diesel Exhaust, Photosynthetic Yield, Gas Exchange

\section{Introduction}

Since Nylander (1866) [1] observed reduced lichen diversity in the wider area of Paris, lichens became known

How to cite this paper: Langmann, U., Madl, P., Türk, R., Hofmann, W. and Brunauer, G. (2014) Sensitivity of Lichens to Diesel Exhaust under Laboratory Conditions. Journal of Environmental Protection, 5, 1331-1341.

http://dx.doi.org/10.4236/jep.2014.513127 
as sensitive biological indicators for air quality. Investigations during the last few decades have shown that also excessive supply of atmospheric nitric compounds threatens plant diversity. Indeed recent research demonstrates that lichens are especially sensitive to this kind of air pollutants [2]-[7].

Lichens are non-vascular symbiotic organism formed by a mutualistic partnership between a fungal species (mycobiont) and one or more algal species and/or cyanobacteria (photobiont). Unlike most other plants, lichens do not have any root system to take up nutriens and water from the soil but instead they are depending on atmospheric deposition for nutrient supply and so they also absorb harmful components directly together with essential nutrients. This may be an advantage in areas with clean air but leads to toxic accumulation effects in heavily polluted areas as these organisms do not possess an excretory system [8].

Emissions from fertilizers, manure of agricultural activities and biomass burning (including forest fires) followed by anthropogenic fossil fuel combustion are the most important sources of ammonia $\left(\mathrm{NH}_{3}\right)$. Especially in urban areas and along highly frequented traffic routes there are elevated levels of ammonia generated by petrol engines with catalysers [9]. In addition, the combustion of fossil fuels by diesel engines is also a major source of nitric oxide $\left(\mathrm{NO}_{\mathrm{x}}\right)$, which is known to be another nitrogen-containing pollutant [10]. Additionally, especially diesel particle matter (DPM) in the exhaust of new-generation heavy-duty diesel engines has been reported to have negative effects on the vitality of lichens [11].

In presence of water vapour and ozone, gaseous ammonia (generated by petrol engines with catalyser) combines very quickly with $\mathrm{NO}_{\mathrm{x}}$ (generated by diesel engines) to ammonium nitrate $\left(\mathrm{NH}_{4} \mathrm{NO}_{3}\right)$ - a fine particle matter. Because this fine particle matter can persist within the atmosphere for long periods, it can even have a negative impact several kilometers away from the site of origin [12] and according to recent investigations lichens take up ammonium nitrate $\left(\mathrm{NH}_{4} \mathrm{NO}_{3}\right)$ by dry deposition [9].

Experiments with nitric acid, a secondary product of $\mathrm{NO}_{\mathrm{x}}$ and (rain)water, revealed significant positive correlations between exposure to traffic pollution and the total nitrogen concentration in lichens [8] [9] [13]. Usually the effects of nitric-pollution are mainly caused by long-term exposure to nitrate and ammonium and lead to a chronic accumulation of nitric compounds in plants [12]. Although nitrogen-compounds are an important nutrient source for both the photobiont and the mycobiont, its excessive supply is stressing these organisms [14]. In particular lichens specialized on nitrogen poor habitats have evolved mechanisms for most efficient nitrogen uptake, so they are particularly sensitive to the excess of nitrogen compounds [15].

Green-algal lichens take up nitrogen in form of ammonium, nitrate and organic nitrogen, while cyanolichens exploit atmospheric $\mathrm{N}_{2}$ [16]. $\mathrm{NO}_{\mathrm{x}}$ as prime nitrogen source can be excluded because when exposed to (rain)water it is converted into the strong acids - nitric acid $\left(\mathrm{HNO}_{3}\right)$ or nitrous acid $\left(\mathrm{HNO}_{2}\right)$ which are leading to sub-optimal $\mathrm{pH}$ conditions for the lichen metabolism and are directly damaging the lichen [9] [17]. Since $\mathrm{NO}_{\mathrm{x}}$ is also part of diesel exhaust it has to be regarded as a major factor leading to reduced lichen diversity which can be observed at traffic-exposed areas [18].

Recently it has been shown that lichen community composition near motorways is shifting towards species associations with more nitrophytic lichens [19]. Generally, changes in N-deposition affect the composition of plant diversity and may induce a dominance of nitrophytic species over those species that are more susceptible to nitric-enrichment in nutrient-poor habitats [20]-[22]. One mechanism leading to this extreme sensitivity of some lichens to excessive supply of nitrogen compounds may be the ability to bind such compounds within cell walls until the concentrations become toxic by causing electrolyte leakage, as was shown for Evernia prunastri by Munzi et al. (2009a, b) [23] [24].

Recent investigations in the Bluntau Valley—a secondary valley of the Salzach Valley (Salzburg, Austria) — demonstrate that this area is heavily affected by airborne pollutants from a motorway which is several kilometers away [19].

For this study we intended to simulate a situation like in the Bluntau Valley by using lichen species with different grades of sensitivity to air pollution which are typically growing in this area. These samples were exposed to diesel exhaust under controlled conditions (apart from other airborne pollutants that may hamper an evaluation of diesel-induced effects). Aerosol concentrations resembled those typically measured along this heavily frequented motorway close to this valley.

The lichen vitality was monitored throughout the experiment by chlorophyll fluorescence and gas exchange measurements. This experiment was done to address several questions. 1) Does diesel exhaust damage lichens? and if so, 2) within which period the damaging effects become apparent? 3) Are all tested species affected to the 
same degree?

\section{Material and Methods}

\subsection{Lichen Material}

The following species were examined in this study: the green algal lichens Pseudevernia furfuracea (L.) Zopf, Hypogymnia physodes (L.) Nyl., Usnea filipendula Stirt., Lobaria pulmonaria (L.) Hoffm. and the cyanolichen Peltigera praetextata (Flörke ex Sommerf.) Zopf.-L. pulmonaria was sampled in Salzburg, Vorderkaser at 690 msm in November and $X$. parietina in Salzburg, Lamprechtshausen at $458 \mathrm{msm}$ in November. All other lichens (P. furfuracea, H. physodes, L. pulmonaria and P. praetextata) were collected in Salzburg, Krimmler Wasserfälle at 1300 - $1320 \mathrm{msm}$ in November. All samples were air-dried at room temperature and then stored at $-20^{\circ} \mathrm{C}$ up to the time they were used in the experiment.

\subsection{Exposure Chamber}

The chamber consisted of a stainless steel case with a volume of about $1 \mathrm{~m}^{3}$ that can be sealed hermetically with an $8 \mathrm{~mm}$ glass-plate. A Philips HQ $400 \mathrm{~W}$ lamp was used as a light source to induce photosynthesis of the lichens inside the chamber. The photon flux density (PFD) on the surface of the lichens $\left(280 \mu \mathrm{mol} \cdot \mathrm{m}^{-2} \cdot \mathrm{s}^{-1}\right) \mathrm{was}$ measured by using a LI-COR Quantum sensor model LI-189. Antistatic Tedlar-bags (capacity 30 L per bag; Linde, Germany) have been filled with diesel exhaust emissions from a Volkswagen transporter without catalyser, model: Kastenwagen LR TDI, version VW 7H/7J (engine displacement: 2461 ccm, 96 kW, year of manufacture 2004). According to specification the vehicle produces $0.691 \mathrm{~g} \cdot \mathrm{km}^{-1} \mathrm{NO}_{\mathrm{x}}$. The diesel aerosols were constantly pumped from the sampling bag into the chamber by using a shunt of a modified paint spray head that led $0.1 \mathrm{~L}$ diesel aerosols per liter of clean humidified air into the chamber at a flow-rate about $3 \mathrm{~L} \cdot \mathrm{min}^{-1}$. Appropriate humidity levels of $85 \% \pm 5 \%$ were provided using a $500 \mathrm{~mL}$ Drechsler impinge flask with an attached Hepafilter capsule (Model PALL PN12144). A water-cooling system was developed to keep the temperature inside the chamber at $19^{\circ} \mathrm{C} \pm 1^{\circ} \mathrm{C}$. The chamber was fitted with various adapters for thermometer, hygrometer and a cable for an internal fan that mixed the air inside.

\subsection{Aerosol Measurements}

Nanoparticles of the diesel exhaust were quantified by a Grimm Scanning Mobility Particle Sizer (SMPS) model 5403 fitted with a long Dynamic Mobility Analyzer (DMA) capable to scan a particle size range of 10.5 to 1050 $\mathrm{nm}$, with associated software version 3.14. According to the dataset (data not shown) the average total particle concentration at a peak load of 28,274 particles per $\mathrm{cm}^{3}$ (standard deviation: 4837) was reached within 12 minutes after the feeding process started. After this peak the particle concentration was constantly decreasing to the half of the maximal load within one hour; two hours after the particle peak load the Tedlar-bag was empty and the chamber was flooded with clean humidified air again. The diesel aerosol particle diameters were ranging from 100 to $1000 \mathrm{~nm}$. The maximal particle concentration in the incubation chamber is corresponding to the overall aerosol concentration found along a local highway in Salzach valley [19] [25].

\subsection{Fluorescence Measurements}

Chlorophyll fluorescence was measured using a Walz photosynthesis yield analyzer model MiniPAM (puls amplitude modulation) following the manufacturer's instructions (Walz GmbH, Effeltrich, 1999, Germany) [26]. False-colour images of whole-thallus chlorophyll fluorescence data were done with a Maxi Version of an Imaging-PAM M-Series according to the user manual (Walz GmbH, Effeltrich, 2009, Germany) [27]. In this study the vitality of lichens is shown by the relation of variable fluorescence to maximal fluorescence $\left(F_{v} / F_{m}\right.$ value) expressing the maximal photochemical quantum yield of photosystem II.

\section{5. $\mathrm{CO}_{2}$ Gas Exchange Measurements}

The current state of the entire lichen (myco- and photobiont) was monitored by gas-exchange measurements using an "open minicuvette system” (CMS 400, Walz, Germany) under constant controlled conditions of temperature $\left(15^{\circ} \mathrm{C}\right)$, light intensity $\left(500 \mu \mathrm{mol} \cdot \mathrm{s}^{-1} \cdot \mathrm{m}^{-2}\right)$ and measuring gas flow $\left(400 \mathrm{~mL} \cdot \mathrm{min}^{-1}\right)$. These measurements 
were done three times for the test samples (at the beginning, in the middle and at the end of the investigations) and twice for the control samples (once before the experiment and once at the end).

\subsection{Treatment}

The incubation experiment with diesel exhaust was carried out for three weeks corresponding to the rhythmic rush hours circles of a local highway: samples were kept under a 10:14 hours day:night regime and exposed for two hours five days a week during the diurnal-phase. On weekends, the samples were kept under dry and cool conditions in closed petri-dish on the shaded windowsill. Before treatment and measurements, the lichens were sprayed with distilled water. Additionally they were dark adapted for 15 minutes minimum before chlorophyll fluorescence measurement using the Walz MiniPAM. Chlorophyll fluorescence was measured before and after every second diesel incubation period, respectively. False colours images of the lichens' chlorophyll fluorescence were taken using the Walz Imaging-PAM system. Imaging-PAM measurements were carried out twice on all diesel exhaust treated samples: once before the experiment (on Nov. $17^{\text {th }}$ ) and then again a few days after the end of the experiment (on Dec. $21^{\text {st }}$ ).

\subsection{Control Samples}

Negative controls were kept under exactly the same conditions (day:night regime and regeneration time) as treated samples but exposed to HEPA-filtered humidified air only. In contrast to the treated samples the controls were frozen again after a single measurement with Imaging-PAM on Nov. $17^{\text {th }}$ due to the sequential order of the experimental timeline.

\section{Results and Discussion}

Measurement of photosynthetic capacity and gas-exchange capacity during the experiment proved a damaging impact of diesel exhaust on the metabolism of all lichens within weeks, though the intensity of these effects were species specific. Photosynthetic capacity was determined by chlorophyll fluorescence methods. Since it is widely accepted that the maximum quantum yield-parameter (expressed as the ratio of variable chlorophyll fluorescence to maximum fluorescence, $\mathrm{F}_{\mathrm{v}} / \mathrm{F}_{\mathrm{m}}$ ) is correlating with stress levels of plants (e.g. [28]-[30] and references therein), this parameter was selected as a measure for the condition of the lichen samples.

Under ideal conditions the $\mathrm{F}_{\mathrm{v}} / \mathrm{F}_{\mathrm{m}}$ maximum of lichens with a green-algal photobiont reaches about 0.60 to 0.76 (e.g. X. parietina). This signal is lower, in the range of max 0.50 to 0.60 in cyanolichens (cyanobacterial photobionts; e.g. P. praetextata) because PSII is missing and PSI gives only a weak signal [31] [32]. Values below 0.1 indicate non-viable material [32].

Figure 1 shows relative changes of $F_{v} / F_{m}$ values of each lichen species during 3 weeks of treatment with exposure-free periods at the weekends (solid lines), while the dotted lines show $F_{v} / F_{m}$ changes of the negative control samples.

In our study we found for all of the investigated lichens that the $F_{v} / F_{m}$ values of exhaust-treated samples (solid lines with squares; Figure 1) were decreasing much stronger during treatment periods than values of control samples (dotted lines with triangles; Figure 1). However, the most noteworthy finding was that the treated samples seemed to recover to some extent during exposure-free times. Since this pattern could not be found for the control samples, which showed rather constant $\mathrm{F}_{\mathrm{v}} / \mathrm{F}_{\mathrm{m}}$ values during the experiment (except $P$. praetextata), we can exclude that this is an experimental artifact. Only in the case of the cyanolichen P. praetextata the control samples also seemed to regenerate during incubation-free times which might be due to an adaptation process to the climatic conditions in the incubation chamber, which seem to be sub-optimal for this lichen species.

P. furfuracea (Figure 1(a)) and H. physodes (Figure 1(b)) reacted strongest to the diesel exhaust treatments. After the first week they had lost about $30 \%$ of their initial $\mathrm{F}_{\mathrm{v}} / \mathrm{F}_{\mathrm{m}}$ values and regained about $97 \%$ of their initial activity within two treatment-free days. During the second week of aerosol-treatment the samples of $P$. furfuracea lost about $32 \%$ of their initial activity followed by a recovery up to $80 \%$ of the original $\mathrm{F}_{\mathrm{v}} / \mathrm{F}_{\mathrm{m}}$ values during the treatment-free period and lost about $37 \%$ of their initial capacity during the third week of treatment.

In contrast to $P$. furfuracea the lichen species $H$. physodes had lost only $22 \%$ of its initial $F_{v} / F_{m}$ values after the second week of treatment but regained about $90 \%$ during the exposure-free weekend. During the third week of treatment $\mathrm{F}_{\mathrm{v}} / \mathrm{F}_{\mathrm{m}}$ of $H$. physodes was reduced again by about $20 \%$ of the initial value.

Throughout the experiment $P$. furfuracea lost about $37 \%$ and $H$. physodes about $20 \%$ of their initial $\mathrm{F}_{\mathrm{v}} / \mathrm{F}_{\mathrm{m}}$ 

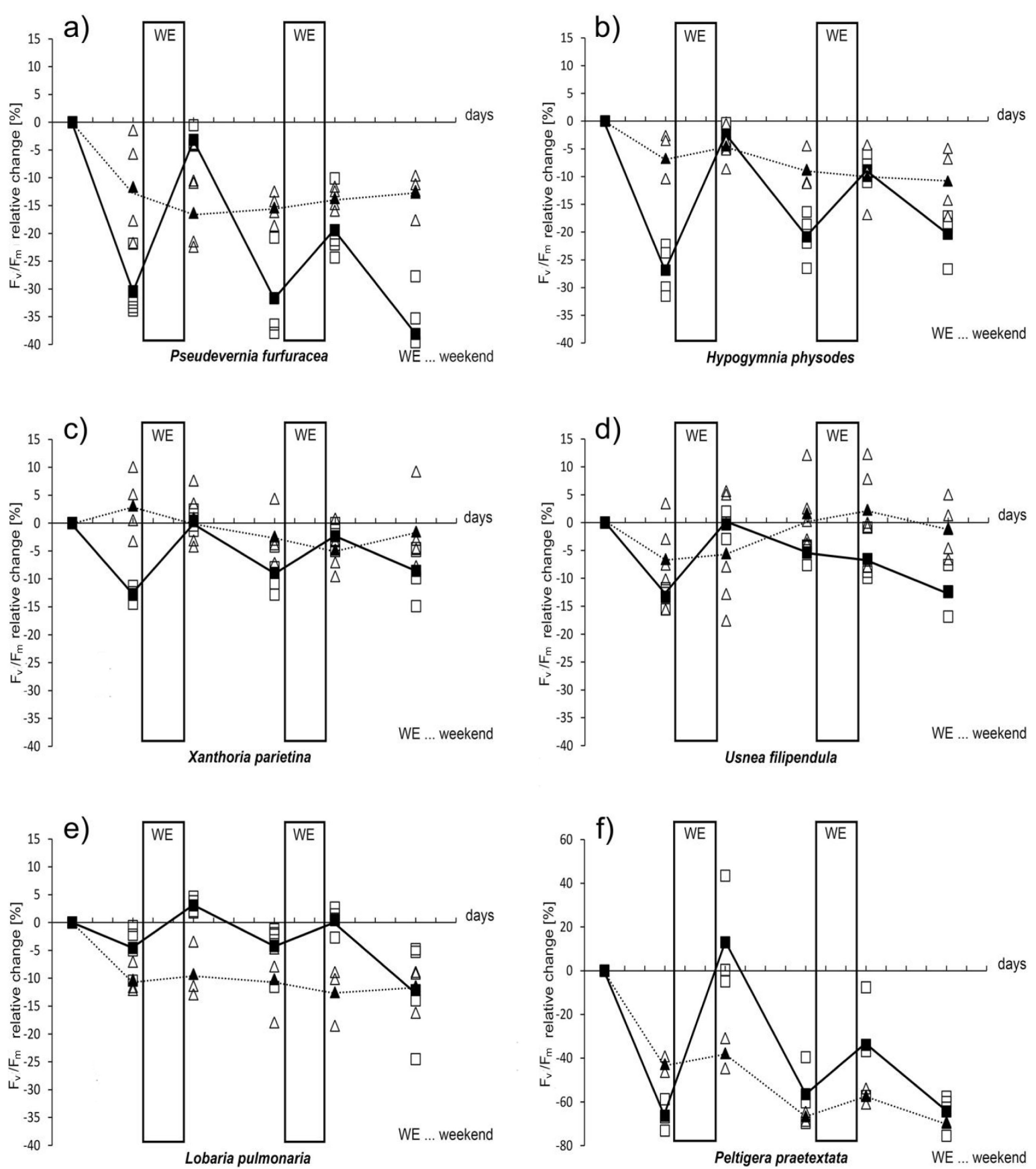

Figure 1. Relative change of $\mathrm{F}_{\mathrm{v}} / \mathrm{F}_{\mathrm{m}}$ values (maximal photosynthetic yield of PSII) of (a) Pseudevernia furfuracea; (b) Hypogymnia physodes; (c) Xanthoria parietina; (d) Usnea filipendula; (e) Lobaria pulmonaria; (f) Peltigera praetextata. Treated samples: white squares; mean value of treated samples: black squares with solid line; control: white triangles; mean value of control: black triangles with dotted line.

values. Both lichen species showed a clear downward trend the longer the samples were exposed to diesel exhaust. This trend confirms observations of Mayer et al. (2013) that chronic deposition of nitric compounds effects lichens more than a single incident [33].

The data of X. parietina (Figure 1(c)), U. filipendula (Figure 1(d)) and L. pulmonaria (Figure 1(e)) did also show a clear decrease in photosynthetic yield during the exposure to diesel exhaust and a recovery after two 
treatment-free days, although the effects were much weaker than with $P$. furfuracea and $H$. physodes. Chlorophyll fluorescence of $L$. pulmonaria did not change strongly within the first two weeks of diesel exhaust exposure, but in the third week of treatment the values dropped sharply. The cyanolichen $P$. praetextata was afflicted most with diesel exhaust.

The untreated samples (negative control) of $P$. furfuracea (dotted line with triangles) showed a reduced activity at the beginning of the experiment, but the samples recovered continuously until the end of the experiment. Similarly, an initial reduction of $\mathrm{F}_{\mathrm{v}} / \mathrm{F}_{\mathrm{m}}$ values of the negative control samples followed by a slight recovery was also found for L. pulmonaria (Figure 1(e)) and for H. physodes (Figure 1(b)). In contrast to the treated samples the control samples were frozen one more time until they were used and we assume that the additional freezing and thawing might have damaged those lichen species, which are already known to be quite sensitive to climatic changes [34]. Bjerke (2009; 2011) has shown that some lichen species can hardly sustain freeze-thaw-cycles especially when they are not absolutely dry [35] [36] and as a consequence, the reason for the lower initial photosynthetic yield levels observed for the control samples of $P$. furfuracea, $H$. physodes, $U$. filipendula, L. pulmonaria and $P$. praetextata (see Figure 1). In the further course of the incubation only the control samples of $X$. parietina and $P$. furfuracea were recovering again while $L$. pulmonaria remained at low $\mathrm{F}_{\mathrm{v}} / \mathrm{F}_{\mathrm{m}}$ values. The $\mathrm{F}_{\mathrm{v}} / \mathrm{F}_{\mathrm{m}}$ values of the controls of $U$. filipendula lost about 7\% after the first week. During the following 10 days the samples seemed to adapt to the conditions in the chamber and recovered continuously with a slight decrease at the end of the incubation period.

In contrast to the tested lichen species with green algal photobionts, the control samples of the cyanolichen $P$. praetextata did not adapt to the incubation conditions and did not recover like control samples of the other lichen species. But in any case, Figures 1(a)-(f) clearly show that every treatment with diesel exhaust has adverse effects on the photosynthetic capacity of the lichens. Such loss of function in PSII may have various causes like inhibited energy transfer from carotenoids to chlorophyll, damage of PSII reaction center complex, increased heat dissipation in PSII antennae to avoid damage, blocked electron transport [37] or inhibition of the repair of PSII because of diminished supply of ATP [38].

Which fraction of the diesel exhaust affects photosynthesis is still speculative at this stage of the investigation since the analysis method allows no clear statement about the type of damage at subcellular level. However, the experiment clearly shows that diesel exhaust exposure is a stress factor that affects the photosynthetic capacity of lichens.

False colour imaging of the photosynthetic condition of samples from three selected lichen species $(H$. physodes, L. pulmonaria and P. furfuracea) using a chlorophyll fluorescence Imaging-PAM (Walz, Effeltrich, Germany) also confirmed the loss of photosynthetic activity (Figure 2). These images are giving an overview of the entire thallus, thus allowing an evaluation of the photosynthetic status of particular thallus parts. This data reveals that especially older parts of the thallus are adversely affected by diesel exhaust: the dark blue colour of the older central parts became turquoise and green corresponding to a total photosynthetic reduction to $60 \%$ and $50 \%$ of a healthy thallus while the younger parts of the thalli remain blue or light blue (particularly see $L$. pulmonaria). False colour pictures of the clean-air-indicator $P$. furfuracea (Figure 2(e) and Figure 2(f)) also proved the sensitivity of this lichen to air pollutants like diesel exhaust: The dark blue colour of the healthy sample turned to green and yellow-green, indicating a loss of more than $50 \%$ of photosynthetic activity.

Additional $\mathrm{CO}_{2}$-exchange measurements could help to draw a more comprehensive picture of the damaging effects on the lichen organism (see supplement data). These results are consistent with the chlorophyll fluorescence measurements and confirm the decrease in photosynthetic capacity during the experiment. But in contrast to chlorophyll fluorescence measurements, the gas exchange measurement gave additional information by providing data concerning the metabolic activity of the mycobiont and the photobiont and hence the vitality status of both lichen bionts. Since it is generally assumed that the mycobiont contributes to the majority of the dark respiration (DR) of a lichen [39] the vitality of both bionts can be estimated by relating the DR to net photosynthesis. At the end of the incubation period almost none of the specimens showed positive net photosynthesis values in the gas-exchange measurements, implying that the algae could no longer sustain the energy requirements of the lichen thallus. In contrast, the untreated reference samples were still capable of net photosynthesis to compensate the total respiration of the thallus. But, contrary to other studies examining the effects of environmental pollution on lichens where the mycobiont was damaged first (e.g. [24] [40]), we found that the mycobiont vitality was affected at a minor level since respiration values of the treated samples were not reduced in the same extent as the assimilation rates of the photobionts (see supplement data). Such diminished photosynthesis 

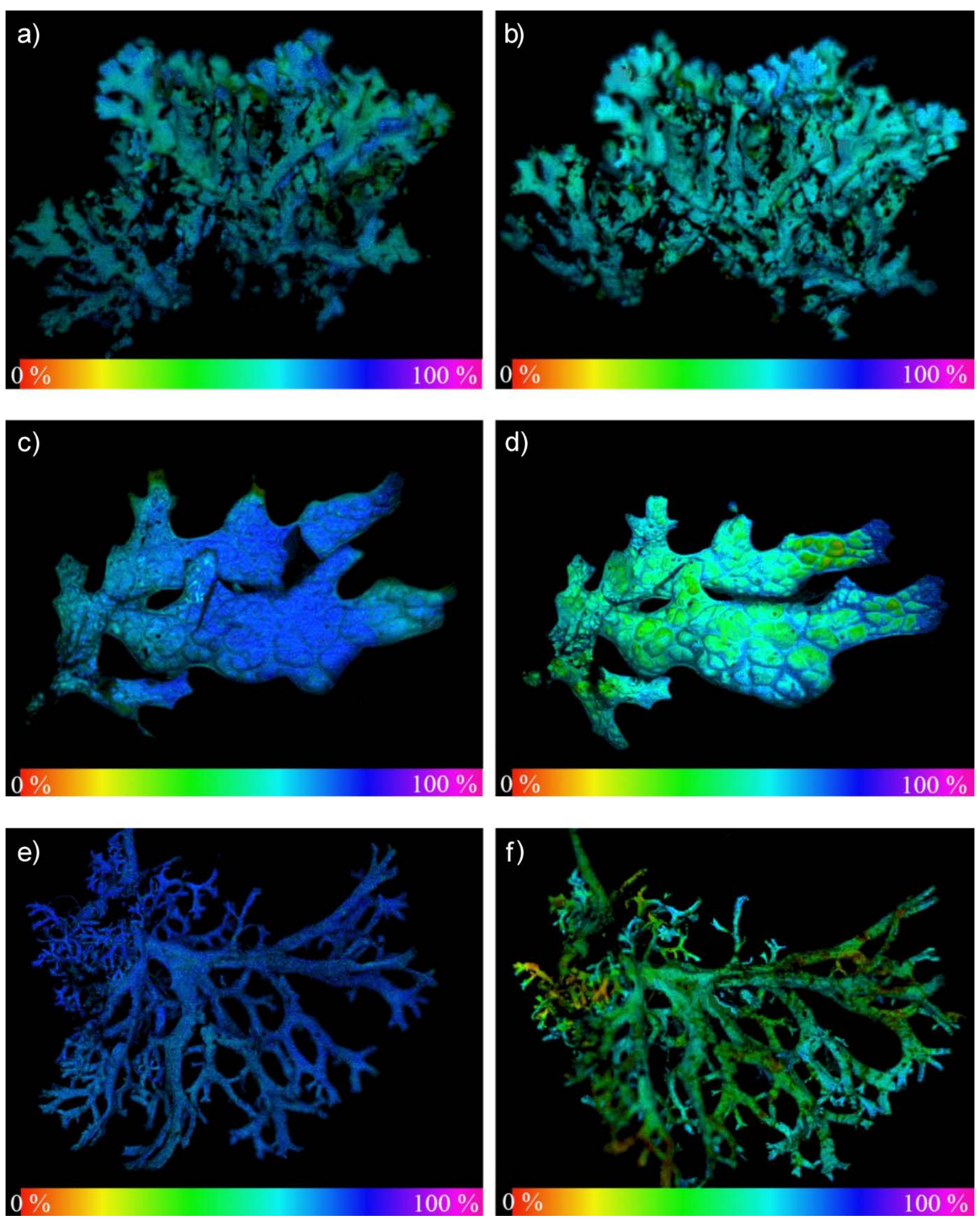

Figure 2. False colour pictures based on $F_{v} / F_{m}$ values of (a) Hypogymnia physodes before and (b) after treatment, (c) Lobaria pulmonaria before and (d) after treatment, (e) Pseudevernia furfuracea before and (f) after treatment.

leads to starvation of the mycobiont and eventually to a metabolic breakdown of the entire lichen.

Possible factors influencing susceptibility of lichens to environmental pollutants might be the different cation exchange capacities of lichen species [6] [40] [41], because the sensitivity decreases in correlation with the 
cation exchange capacity [42]. This would indicate that also charged particles or ions from diesel exhaust are bound to the mycobiont cell walls and distributed by apoplastic transport to other parts of the thallus. This mechanism might play a role in this investigation too, but since results from the chlorophyll fluorescence and the gas-exchange measurements suggest that mainly the algae were damaged, it is more likely that the algae were directly taking up the pollutants in its aerosol form. This finding is in agreement with a study of Hauck (2010) who confirmed that it is the identity of the photobiont that plays a key role in the lichens' tolerance to an excess supply of ammonium and nitrate [16]. Recent studies have demonstrated that environmental stressors act primarily by inhibiting the repair of PSII where much energy is needed to restore photosynthesis function by a wide range of mechanisms, like the re-synthesis of affected proteins such as the D1 protein of PSII [43] [44]. If these repair mechanisms are impaired, photoinhibition will lead to a reduction of photosynthetic productivity and the energy produced will not be sufficient to sustain cellular structures [38] [43] [44]. In our experiment this diminished synthesis of ATP might also have been a limiting factor for the repair of PSII [38] [43] [45]. For example, investigations using $\mathrm{HNO}_{3}$ exposure showed a negative effect on several lichens species and the physiological condition of especially sensitive lichens was affected dramatically [46] [47]. The data of these investigations are well comparable with our data, as a typical component of diesel exhaust is particle matter of $\mathrm{NO}_{\mathrm{x}}$ which were shown by our investigations to impact significantly the photosynthesis process.

\section{Conclusion}

This study suggests that lichens are directly affected by diesel exhaust in concentrations similar to those of rush-hour exposure events as observed at a motorway in Salzburg, Austria. The impact on the lichens became apparent in reduced chlorophyll fluorescence values $\left(\mathrm{F}_{\mathrm{v}} / \mathrm{F}_{\mathrm{m}}\right.$ values) during diesel exhaust exposure. Additional gas exchange measurements showed that also the net photosynthesis rates of the test samples were progressively decreasing, while dark respiration was affected only to a minor extent, suggesting that the treatment had more impact on the photobiont than on the mycobiont in the short term. This will also lead to a metabolic breakdown of the whole lichen by starvation in the long term if the organism is damaged too much to restore the photosynthetic activity. False colour imaging also revealed that older parts of the thallus are much more affected by the treatment than younger parts. Since diesel exhaust is a complex mixture of substances in different phases (gaseous to fine particle matter), it is not clear which of the compounds account for this observed impact. But the most striking finding of this study is that diesel exhaust treated samples could recover to some extent during treatment-free periods, although they did not reach their initial capacities. The practical implications of these results are that low-traffic periods could indeed be beneficial for the biodiversity in ecologically sensitive areas.

\section{Acknowledgements}

This project was made possible from a grant provided by the local county (Salzburger Landesregierung, Dr. A. Falkensteiner, Dr. O. Gläser, Dr. C. Sperka-Gottlieb). The authors thank Dr. Erhard Pfündel and Dr. Oliver Meyerhoff (Walz Company, Effeltrich) for the possibility to use Imaging-PAM. We are grateful to Stiftungsund Förderungsgesellschaft of the University of Salzburg for covering the publication fees.

\section{References}

[1] Nylander, M. (1866) Les Lichens du Jardin du Luxembourg. Bulletin de la Société botanique de France, 13, $364-371$.

[2] De Wit, T. (1983) Lichens as Indicator for Air Quality. Environmental Monitoring and Assessment, 3, 273-282. http://dx.doi.org/10.1007/BF00396221

[3] Nimis, P.L., Scheidegger, C. and Wolseley, A.P. (2002) Monitoring with Lichens-Monitoring Lichens. Kluwer Academic Publishers, Dordrecht.

[4] Conti, M.E. and Cecchetti, G. (2001) Biological Monitoring: Lichens as Bioindicators of Air Pollution Assessment—A Review. Environmental Pollution, 114, 471-492. http://dx.doi.org/10.1016/S0269-7491(00)00224-4

[5] Olsen, H.B., Berthelsen, K., Andersen, H.V. and Søchting, U. (2010) Xanthoria Parietina as a Monitor of GroundLevel Ambient Ammonia Concentrations. Environmental Pollution, 158, 455-461. http://dx.doi.org/10.1016/j.envpol.2009.08.025

[6] Munzi, S., Pisani, T., Paoli, L. and Loppi, S. (2010) Time- and Dose-Dependency of the Effects of Nitrogen Pollution on Lichens. Ecotoxicology and Environmental Safety, 73, 1785-1788. http://dx.doi.org/10.1016/j.ecoenv.2010.07.042 
[7] Sparrius, L.B. (2007) Response of Epiphytic Lichen Communities to Decreasing Ammonia Air Concentrations in a Moderately Polluted Area of the Netherlands. Environmental Pollution, 146, 375-379.

http://dx.doi.org/10.1016/j.envpol.2006.03.045

[8] Coffey, H.M.P. and Fahrig, L. (2012) Relative Effects of Vehicle Pollution, Moisture and Colonization Sources on Urban Lichens. Journal of Applied Ecology, 49, 1467-1474.

[9] Frahm, J.P., Janßen, A.M., Schumacher, J., Thönnes, D., Hensel, S., Heidelbach, B. and Erler, D. (2009) Das Nitrophytenproblem bei epiphytischen Flechten-Eine Synthese. Archive for Lichenology, 5, 1-8.

[10] Bobbink, R., Hicks, K., Galloway, J., Spranger, T., Alkemade, R., Ashmore, M., Bustamante, M., Cinderby, S., Davidson, E., Dentener, F., Emmett, B., Erisman, J.W., Fenn, M., Gilliam, F., Nordin, A., Pardo, L. and De Vries, W. (2010) Global Assessment of Nitrogen Deposition Effects on Terrestrial Plant Diversity: A Synthesis. Ecological Applications, 20, 30-59. http://dx.doi.org/10.1890/08-1140.1

[11] Frahm, J.P. (2008) Überdüngung und Versalzung durch Katalysatoren? Nitrophile Moose und Flechten nehmen zu. Biologie in unserer Zeit, 38, 94-101. http://dx.doi.org/10.1002/biuz.200810362

[12] Lovett, G.M., Tear, T.H., Evers, D.C., Findlay, S.E.G., Cosby, B.J., Dunscomb, J.K., Driscoll, C.T. and Weathers, K.C. (2009) Effects of Air Pollution on Ecosystems and Biological Diversity in the Eastern United States. Annals of the New York Academy of Sciences, 1162, 99-135. http://dx.doi.org/10.1111/j.1749-6632.2009.04153.x

[13] Gombert, S., Asta, J. and Seaward, M.R.D. (2003) Correlation between the Nitrogen Concentration of Two Epiphytic Lichens and the Traffic Density in an Urban Area. Environmental Pollution, 123, 281-290. http://dx.doi.org/10.1016/S0269-7491(02)00367-6

[14] Johansson, O., Nordin, A., Olofsson, J. and Palmqvist, K. (2010) Responses of Epiphytic Lichens to an Experimental Whole-Tree Nitrogen-Deposition Gradient. New Phytologist, 188, 1075-1084. http://dx.doi.org/10.1111/j.1469-8137.2010.03426.x

[15] Dahlman, L., Persson, J., Palmqvist, K. and Näsholm, T. (2004) Organic and Inorganic Nitrogen Uptake in Lichens. Planta, 219, 459-467. http://dx.doi.org/10.1007/s00425-004-1247-0

[16] Hauck, M. (2010) Ammonium and Nitrate Tolerance in Lichens. Environmental Pollution, 158, 1127-1133. http://dx.doi.org/10.1016/j.envpol.2009.12.036

[17] Burton, L.D. (2013) Introduction to Forestry Science. Delmar, New York.

[18] Madl, P., Heinzelmann, E., Hofmann, W. and Türk, R. (2010) Motorway Exhaust Aerosols and Their Effects on Epiphytic Lichen Populations. Gefahrstoffe-Reinhaltung der Luft/Air Quality Control, 4, 147-153.

[19] Madl, P. (2009) Anthropogenic Environmental Aerosols: Measurements and Biological Implication. Ph.D. Dissertation, University of Salzburg, Salzburg.

[20] Frati, L., Santoni, S., Nicolardi, V., Gaggi, C., Brunialti, G., Guttova, A., Gaudino, S., Pati, A., Pirintsos, S. and Loppi, S. (2007) Lichen Biomonitoring of Ammonia Emission and Nitrogen Deposition around a Pig Stockfarm. Environmental Pollution, 146, 311-316. http://dx.doi.org/10.1016/j.envpol.2006.03.029

[21] Bowman, W.D., Gartner, J.R., Holland, K. and Wiedermann, M. (2006) Nitrogen Critical Loads for Alpine Vegetation and Terrestrial Ecosystem Response: Are We There Yet? Ecological Applications, 16, 1183-1193. http://dx.doi.org/10.1890/1051-0761(2006)016[1183:NCLFAV]2.0.CO;2

[22] Riddell, J., Jovan, S., Padgett, P.E. and Sweat, K. (2011) Tracking Lichen Community Composition Changes Due to Declining Air Quality over the Last Century: The Nash Legacy in Southern California. Bibliotheca Lichenologica, 106, 263-277.

[23] Munzi, S., Pisani, T. and Loppi, S. (2009) The Integrity of Lichen Cell Membrane as a Suitable Parameter for Monitoring Biological Effects of Acute Nitrogen Pollution. Ecotoxicology and Environmental Safety, 72, 2009-2012. http://dx.doi.org/10.1016/j.ecoenv.2009.05.005

[24] Munzi, S., Pirintsos, A. and Loppi, S. (2009) Chlorophyll Degradation and Inhibition of Polyamine Biosynthesis in the Lichen Xanthoria Parietina under Nitrogen Stress. Ecotoxicology and Environmental Safety, 72, 281-285. http://dx.doi.org/10.1016/j.ecoenv.2008.04.013

[25] Kwasny, F., Madl, P. and Hofmann, W. (2009) Urban Aerosols in the City and County of Salzburg-Particle Concentration, Size Distribution and Air Quality Data. Field Campaign Commissioned for Salzburg County (German Title: Nanopartikel in Salzburg Stadt und Umland Sommer- und Wintererhebung). In: Madl, P., Ed., Anthropogenic Environmental Aerosols: Measurements and Biological Implications, Ph.D. Dissertation.

[26] Walz GmbH (1999) Photosynthesis Yield Analyzer, Mini-PAM Portable Chlorophyll Fluorometer, Handbook of Operation. Walz GembH, Effeltrich.

[27] Walz GmbH (2009) Imaging-PAM Chlorophyll Fluorometer, Instrument Description. Walz GmbH, Effeltrich.

[28] Gross, R.E., Pugno, P. and Dugger, W.M. (1970) Observations on the Mechanism of Copper Damage in Chlorellal. 
Plant Physiology, 46, 183-185. http://dx.doi.org/10.1104/pp.46.2.183

[29] Parkhill, J., Maillet, G. and Cullen, J.J. (2001) Fluorescence-Based Maximal Quantum Yield for PSII as a Diagnostic of Nutrient Stress. Journal of Phycology, 37, 517-529. http://dx.doi.org/10.1046/j.1529-8817.2001.037004517.x

[30] Willits, D.H. and Peet, M.M. (2001) Measurement of Chlorophyll Fluorescence as a Heat Stress Indicator in Tomato: Laboratory and Greenhouse Comparisons. Journal of the American Society for Horticultural Science, 126, 188-194.

[31] Jensen, M. (1994) Assessment of Lichen Vitality by the Chlorophyll Fluorescence Parameter $\mathrm{F}_{\mathrm{v}} / \mathrm{F}_{\mathrm{m}}$. Cryptogamic Botany, 4, 187-192.

[32] Jensen, M. and Kricke, R. (2002) Chlorophyll Fluorescence Measurements in the Field: Assessment of the Vitality of Large Numbers of Lichen Thalli. In: Monitoring with Lichens-Monitoring Lichens, Kluwer Academic Publishers, London, 327-332. http://dx.doi.org/10.1007/978-94-010-0423-7 29

[33] Mayer, W., Pfefferkorn-Dellali, V., Türk, R., Dullinger, S., Mirtl, M. and Dirnböck, T. (2013) Significant Decrease in Epiphytic Lichen Diversity in a Remote Area in the European Alps, Austria. Basic and Applied Ecology, 14, 396-403. http://dx.doi.org/10.1016/j.baae.2013.05.006

[34] Ellis, C.J. and Coppins, B.J. (2007) Changing Climate and Historic-Woodland Structure Interact to Control Species Diversity of the "Lobarion” Epiphyte Community in Scotland. Journal of Vegetation Science, 18, 725-734. http://dx.doi.org/10.1111/j.1654-1103.2007.tb02587.x

[35] Bjerke, J.W. (2009) Ice Encapsulation Protects Rather than Disturbs the Freezing Lichen. Plant Biology, 11, $227-235$. http://dx.doi.org/10.1111/j.1438-8677.2008.00113.x

[36] Bjerke, J.W. (2011) Winter Climate Change: Ice Encapsulation at Mild Subfreezing Temperatures Kills Freeze-Tolerant Lichens. Environmental and Experimental Botany, 72, 404-408. http://dx.doi.org/10.1016/j.envexpbot.2010.05.014

[37] Xue, W., Li, X.Y., Zhu, J.T. and Lin, L.S. (2012) Effects of Temperature and Irradiance on Photosystem Activity during Alhagi sparsifolia Leaf Senescence. Biologia Plantarum, 56, 785-788. http://dx.doi.org/10.1007/s10535-012-0145-8

[38] Murata, N., Takahashi, S., Nishiyama, Y. and Allakhverdiev, S.I. (2007) Photoinhibition of Photosystem II under Environmental Stress. Biochimica et Biophysica Acta, 1767, 414-421. http://dx.doi.org/10.1016/j.bbabio.2006.11.019

[39] Quispel, A. (1960) Respiration of Lichens. In: Wolf, J., Ed., Pflanzenatmung Einschließlich Gärung und Säurestoffwechsel (Handbuch der Pflanzenphysiologie), Springer Berlin, Heidelberg, New Yor.

[40] Gaio-Oliveira, G., Dahlman, L., Palmqvist, K., Martins-Loução, M.A. and Máguas, C. (2005) Nitrogen Uptake in Relation to Excess Supply and Its Effects on the Lichens Evernia prunastri (L.) Ach and Xanthoria parietina (L.) Th. Fr. Planta, 220, 794-803. http://dx.doi.org/10.1007/s00425-004-1396-1

[41] Meychik, N.R., Lyubimova, E.G. and Yermakov, I.P. (2010) Ion-Exchange Properties of the Cell Wall of Reindeer Lichen Cladonia rangiferina. Russian Journal of Plant Physiology, 57, 260-266. http://dx.doi.org/10.1134/S1021443710020147

[42] Munzi, S., Loppi, S., Cruz, C. and Branquinho, C. (2011) Do Lichens Have “Memory” of Their Native Nitrogen Environment? Planta, 233, 333-342. http://dx.doi.org/10.1007/s00425-010-1300-0

[43] Nixon, P.J., Michoux, F., Yu, J., Boehm, M. and Komenda, J. (2010) Recent Advances in Understanding the Assembly and Repair of Photosystem II. Annals of Botany, 106, 1-16. http://dx.doi.org/10.1093/aob/mcq059

[44] Keren, N. and Krieger-Liszkay, A. (2011) Photoinhibition: Molecular Mechanisms and Physiological Significance. Physiologia Plantarum, 142, 1-5. http://dx.doi.org/10.1111/j.1399-3054.2011.01467.x

[45] Takahashi, S. and Murata, N. (2008) How Do Environmental Stresses Accelerate Photoinhibition? Trends in Plant Science, 13, 178-182. http://dx.doi.org/10.1016/j.tplants.2008.01.005

[46] Riddell, J., Nash, T.H. and Padgett, P. (2008) The Effect of $\mathrm{HNO}_{3}$ Gas on the Lichen Ramalina menziesii. FloraMorphology, Distribution, Functional Ecology of Plants, 203, 47-54. http://dx.doi.org/10.1016/j.flora.2007.10.001

[47] Riddell, J., Padgett, P.E. and Nash, T.H. (2012) Physiological Responses of Lichens to Factorial Fumigations with Nitric Acid and Ozone. Environmental Pollution, 170, 202-210. http://dx.doi.org/10.1016/j.envpol.2012.06.014 


\section{Electronic Supplementary Material}

Table S1. $\mathrm{CO}_{2}$ gas exchange measurements of Hypogymnia physodes, Pseudevernia furfuracea, Xanthoria parietina, Usnea filipendula, Peltigera praetextata, Lobaria pulmonaria. The abbreviations indicate the lichen names, specimen numbers and references (ref).

\begin{tabular}{|c|c|c|c|c|c|c|c|c|c|c|c|c|}
\hline \multicolumn{13}{|l|}{$\begin{array}{l}\mathrm{CO}_{2} \text { Gas exchange } \\
{\left[\mathrm{mg} \mathrm{CO}_{2} \mathrm{~g}^{-1} \cdot \mathrm{h}^{-1}\right]}\end{array}$} \\
\hline & Нуро01 & Pseudev03 & Pseud01 & Xanth01 & Usnea02 & Pelt02 & Lob01 & & & & & \\
\hline \multicolumn{13}{|l|}{$21.11 .201115^{\circ} \mathrm{C}$} \\
\hline without light & 1.6 & 0.8 & 1.7 & 2.7 & 2.3 & 4.1 & 1.5 & & & & & \\
\hline with light & -1.3 & -3.6 & -3.3 & -3.7 & -8.9 & -6.7 & -0.9 & & & & & \\
\hline \multicolumn{13}{|l|}{ 7.12.2011 $15^{\circ} \mathrm{C}$} \\
\hline without light & 1.0 & 1.1 & 1.2 & 1.8 & 1.6 & 2.2 & 0.3 & & & & & \\
\hline with light & 0.1 & 0.3 & -0.1 & -1.0 & -0.5 & 9.7 & -0.1 & & & & & \\
\hline \multicolumn{13}{|l|}{$15.12 .201115^{\circ} \mathrm{C}$} \\
\hline without light & 0.5 & 1.3 & 0.6 & 1.2 & 1.0 & 1.9 & 0.1 & & & & & \\
\hline \multirow[t]{2}{*}{ with light } & 0.2 & 0.7 & 0.1 & 0.6 & 0.4 & 1.2 & 0.0 & & & & & \\
\hline & $\begin{array}{l}\text { Hypo } \\
\text { 07ref }\end{array}$ & $\begin{array}{l}\text { Hypo } \\
\text { 08ref }\end{array}$ & $\begin{array}{l}\text { Pseud } \\
\text { 07ref }\end{array}$ & $\begin{array}{l}\text { Pseud } \\
\text { 08ref }\end{array}$ & $\begin{array}{l}\text { Xanth } \\
\text { 08ref }\end{array}$ & $\begin{array}{l}\text { Xanth } \\
\text { 09ref }\end{array}$ & $\begin{array}{l}\text { Usnea } \\
\text { 05ref }\end{array}$ & $\begin{array}{l}\text { Usnea } \\
\text { 06ref }\end{array}$ & $\begin{array}{l}\text { Pelt } \\
\text { 06ref }\end{array}$ & $\begin{array}{l}\text { Pelt } \\
\text { 07ref }\end{array}$ & $\begin{array}{l}\text { Lob } \\
\text { 07ref }\end{array}$ & $\begin{array}{l}\text { Lob } \\
\text { 08ref }\end{array}$ \\
\hline \multicolumn{13}{|l|}{$11.1 .201215^{\circ} \mathrm{C}$} \\
\hline without light & 0.6 & 1.1 & 0.2 & 1.3 & 0.1 & 1.0 & 2.1 & 0.9 & 3.1 & 2.2 & 1.1 & 0.1 \\
\hline with light & -0.1 & -1.9 & -0.4 & -2.3 & -0.5 & -0.4 & -2.2 & -0.7 & -10.9 & -10.7 & -5.0 & -5.0 \\
\hline \multicolumn{13}{|l|}{ 3.2.2012 $15^{\circ} \mathrm{C}$} \\
\hline without light & 0 & 0.7 & 0.2 & 1.0 & 0.4 & 0.5 & 1.1 & 0.6 & 5.2 & 3.1 & 2.0 & 1.4 \\
\hline with light & -0.4 & -1.5 & -0.9 & -1.3 & -0.9 & -1.0 & -0.9 & -1.3 & -2.8 & -4.7 & -4.2 & -4.8 \\
\hline
\end{tabular}


Scientific Research Publishing (SCIRP) is one of the largest Open Access journal publishers. It is currently publishing more than 200 open access, online, peer-reviewed journals covering a wide range of academic disciplines. SCIRP serves the worldwide academic communities and contributes to the progress and application of science with its publication.

Other selected journals from SCIRP are listed as below. Submit your manuscript to us via either submit@scirp.org or Online Submission Portal.
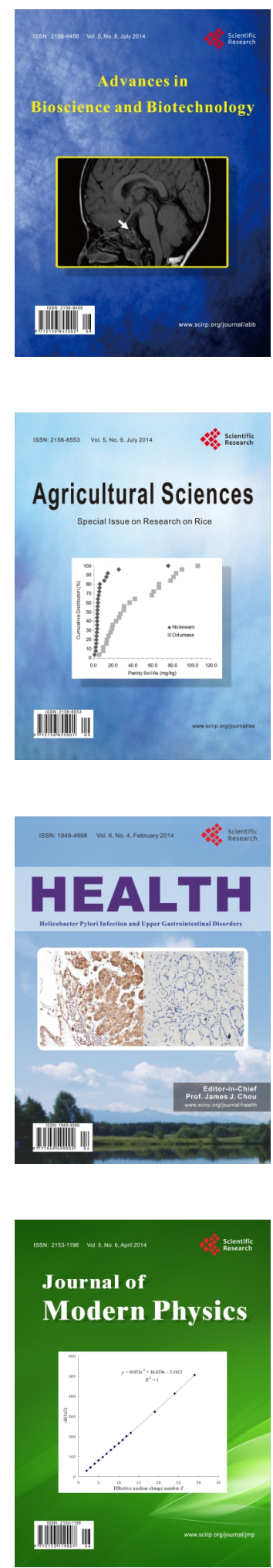
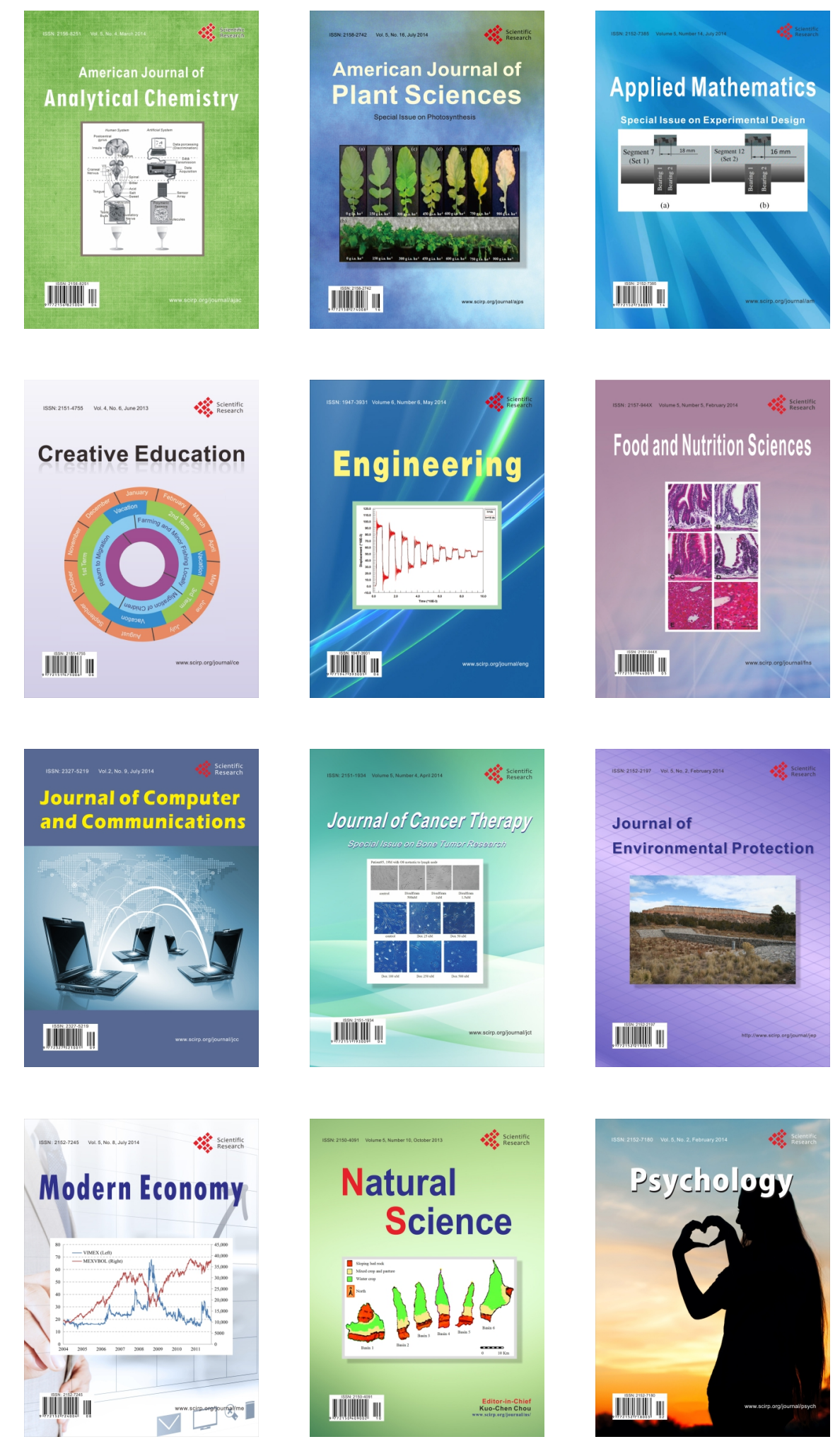